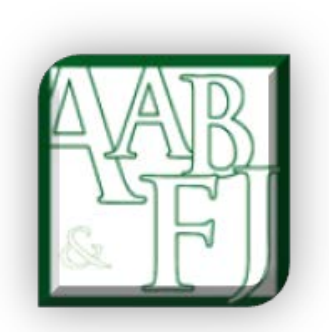

\title{
Corporate Governance Compliance and Discretionary Accruals: New Zealand Evidence
}

\author{
Md. Borhan Uddin Bhuiyan ${ }^{1}$, Jamal Roudaki² \& Murray Clark²
}

\begin{abstract}
The purpose of this paper is to investigate the effect of better compliance with corporate governance regulation on managerial accruals (discretionary accruals) in New Zealand listed companies. Unlike previous research of earnings management, Jones model (Jones 1991), Modified Jones model (Dechow, Sloan, \& Sweeney, 1995) and Performance Matched Accruals Model (Kothari, Leone, \& Wasley, 2005) this research focuses on free cash flow as a measure of discretionary accruals instead of cash flow from operating activities. Univariate and multivariate regression analysis was done on 70 New Zealand listed firms over the period of 2000 - 2007 (inclusive). Results found that better compliance with corporate governance reduces discretionary accruals implying lower managerial opportunistic behaviour. Consistent with existing theories and models of discretionary accruals, this research documents that free cash flow increase managerial discretion by comparing with commonly used accruals model such as Jones Model, Modified Jones Model and Performance Matched Accruals Model. This study provides insights to regulators in developing corporate governance and financial reporting guidelines. It suggests that 'Comply or Explain' form of soft regulation reduces managerial discretion with stock exchange listing. This research uses a comparative analysis of traditional discretionary accrual measure with free cash flow approach of discretionary accruals. Moreover, an integration approach of discretionary accrual measure was never done in New Zealand. ${ }^{3}$
\end{abstract}

Keywords: Corporate Governance Index; Discretionary Accruals; Free Cash Flow; Performance Matched Free Cash Flow; New Zealand.

JEL Codes: M40

\footnotetext{
${ }^{1}$ Massey University, New Zealand. Email: m.b.u.bhuiyan@massey.ac.nz

${ }^{2}$ Lincoln University, New Zealand

3 This paper is based on the PhD thesis of the first author and presented at Asian Academic Accounting Association 2010', Bangkok, Thailand. The authors would like to thank the conference participants for helpful comments on an earlier version of the paper.
} 


\section{Introduction}

This paper documents the association between corporate governance compliance and performance matched free cash flow discretionary accruals. Free cash flow (FCF) is the accumulation of cash flow from operating and investing activities and includes all cash flows relating to property, plant and equipment and investment in the balance sheet. It has been suggested that free cash flow is better matched with earnings (Dechow \& Ge, 2006), and there is a considerable body of literature that defines total accruals as the difference between net income and cash flow from operating activities (Dechow, Sloan, \& Sweeney, 1995; Xie, Davidson, \& DaDalt, 2003). This traditional approach has been extended by Dechow \& Ge (2006) who define total accruals as the difference between earnings and free cash flow. Recent research studies have used the free cash flow approach to accruals measurement (Bukit \& Iskandar, 2009).

Opportunities for earnings management are higher with the increase of free cash flow in business and, in the absence of proper monitoring of management; the risk that money might be misused by investing in less profitable projects is increased. Research studies on corporate governance and earnings management suggest that better corporate governance measures such as having independent directors, supervisory committees (such as the audit committee, nomination committee and remuneration committee), and quality external audits, can reduce opportunistic behaviour by management.

Cash flow is an important basis for accrual measurement (Ingram \& Lee, 2007). Prior literature on earnings management focused on identifying and expanding the set of variables that influence discretionary accruals, using cash flow from operating activities (Leuz, Nanda, \& Wysocki, 2003; McNichols \& Wilson, 1988; Richardson, Sloan, Soliman, \& Tuna, 2005; Siregar \& Utama, 2008; Xie, et al., 2003). However, free cash flow has not been considered when calculating total accruals in previous studies. As stated above, FCF is the combination of cash flow from operating activities and investing activities, which reflects the impact of cash spending on fixed assets and investments. Companies operating with high FCF provide greater opportunities for opportunistic behaviour by management. Therefore it is appropriate to suggest that FCF better reflects accruals for individual firms.

This paper is different in compare with existing research based on US environment and contributes in three ways; firstly, New Zealand corporate regulation is comparatively more flexible than USA where management is strictly monitored, controlled and penalised for wrong forecast and earnings engineering. Moreover market regulators and the New Zealand Institute of Chartered Accountants (NZICA) are more reluctant to identify earnings management. Secondly, corporate ownership structure in New Zealand tends to concentrate into fewer shareholders whereas US firms are owned by scattered owners caused more possibility of earnings management. Finally, monitoring mechanisms such as corporate governance regulations in New Zealand are 'comply or explain' (non-mandatory) in comparison with US 'Act based' regulations.

General findings from prior research indicate that discretionary accruals are affected by corporate governance factors such as the composition of the board of directors, CEO duality, the composition of the audit committee, and auditor independence (Bukit \& Iskandar, 2009; Klein, 2002, 2003; Larcker, Richardson, \& Tuna, 2007; Richardson, et al., 2005; Romano, 2005; Siregar \& Utama, 2008). Firm specific characteristics such as firm size, leverage and profitability have also been documented as determinants of discretionary accruals. Companies operating for a long period of time are expected to have improved corporate governance practices (Fasterling, 2005). Stakeholders, therefore, get the benefits of better monitoring activities. This paper extends earlier research studies by incorporating company age and stock exchange listings as determinants of earnings management. 
Furthermore, this paper also argues that a company operating for a long time under listing status reduces earnings management.

The paper proceeds as follows: Section two presents a literature review of earnings management and corporate governance. Hypotheses are developed in Section three. Sections four and five explain the sampling process used and the research methodology followed. In Section six, univariate and multivariate analyses are discussed, which leads to Section seven, the conclusion of the paper.

\section{Literature Review}

The thread of earnings management essentially commenced in 1985 with the publication of Healy's research, closely followed by DeAngelo's research in 1986. Both of them focused on total accruals and changes in accruals as a measure of discretionary acts by management in order to manage earnings. Healy (1985) found that accrual policies of managers are related to bonus incentives in their employment contracts. However, DeAngelo (1986) found sharp contrast with Healy (1985). Both authors used accrual methodology and each found evidence of income manipulation in a different setting. DeAngelo calculated non-discretionary accruals based on lagged total accrual whereas Healy measured earnings based on comparing means of total accruals scaled by total assets. Neither of these researchers separated out nondiscretionary factors - this first occurred when Jones (1991) used a linear regression approach and controlled for non-discretionary accrual factors including sales revenue and property, plant and equipment.

A different approach to earnings management research was introduced by McNicols and Wilson (1988) who focussed on specific accruals within industry settings. McNicols and Wilson (1988) modelled earnings management on a single accrual factor, the provision for bad debts, instead of collective factors of accruals using Generally Accepted Accounting Principles (GAAP). Moyer (1990) examined the incentives for commercial bank managers to adjust accounting measures used by regulators and legislators. Petroni (1992) investigated the extent to which the biased application of accounting discretion by managers of property/casualty insurers affects the estimation error in claim loss reserves, finding that managers of financially weak insurance companies bias estimates of claim loss reserves downwards relative to financially strong insurers.

The behaviour of earnings around a specified benchmark is another approach to earnings management research. Burgstahler and Dichev (1997) provide evidence that earnings management occurs in order to avoid reporting decreases in earnings or losses. It has also been suggested that earnings management occurs in order to report positive profit, sustain recent performance, and meet analysts' forecasts, in that order (Degeorge, Patel, \& Zeckhauser, 1999).

Dechow et al. (1995) introduced the Modified Jones Model, which has become one of the most widely-used models in earnings management research. The Modified Jones Model includes an adjustment to sales based on the change in the amount of receivables. Whereas the Jones Model implicitly assumes that discretion is not exercised over revenue in either the estimation period or the event period, the Modified Jones Model assumes that all changes in credit sales in the event period result from earnings management (P. M. Dechow, et al., 1995). The Jones Model focuses on the manipulation of bad debt expenses but underestimates managed earnings when sales are manipulated. In contrast, the Modified Jones Model overestimates the magnitude of earnings management (Ronen \& Yaari, 2007).

The following five sub-sections survey the relevant literature on regulation and corporate governance indicators related to earnings management. 


\subsection{Regulation and Earnings Management}

Regulation is an important determinant of earnings management. Both voluntary and mandatory regulations increase disclosures to shareholders, reduce information asymmetry, and managerial discretionary power to manage earnings. Disclosure of information reduces the cost of capital and provides higher earnings quality (Francis, Nanda, \& Olsson, 2008). A weak legal environment might facilitate opportunistic earnings management, which results in lower earnings quality. Although soft regulations strengthen the rights of minority shareholders, they cannot rely on the courts as legal processes remain slow and ineffective (Ball, Kothari, \& Robin, 2000). They also found that earnings management is inversely related to the strength of the regulation and litigation environment.

Stock market authorities have become increasingly anxious about the implementation of corporate governance regulations following many high profile corporate collapses and accounting manipulations that have occurred in recent years. Corporate governance regulations were introduced following the Cadbury Report in 1992 (Cadbury, 1992) and, more recently, tightened in the Sarbanes-Oxley Act 2002, but recent literature suggests that corporate governance regulations are irrelevant and competing regulators implement them irrespective of necessity (Romano, 2005). Nonetheless, this flow of regulation allows regulators to facilitate better policy and allows flexibility to the organisations as one code does not fit all sectors and companies.

\subsection{Board of Directors and Earnings Management}

GAAP requires firms to use accrual accounting, but this also allows management to control the timing of accrual expenditures (Xie, et al., 2003). However, it is over to the board of directors to monitor and control these discretionary acts of management. Independent outside directors provide a measure of protection against this agency problem (Weisbach, 1988), so it is expected that the composition of the board will be a factor that influences the extent to which a company engages in earnings management since independent outsider directors monitor management more effectively than inside directors (Vafeas, 2000; Xie, et al., 2003). Unfortunately, non-executive directors may not act as good monitors if they have a significant financial interest in the company (Luan \& Tang, 2007; Peasnell, Pope, \& Young, 2005; Tosi, Shen, \& Gentry, 2003), they have other directorships that compete for their time (i.e. they are too busy), they have limited time to devote to the affairs of the company, or they owe their positions to existing management and therefore their loyalty is more to that management than to the company (Hart, 1995). A large board may include a number of independent directors, but this may also result in greater bureaucracy and less functionality than a board that is numerically smaller. Nevertheless, a large board with more independent directors is better positioned to prevent earnings management (Xie, et al., 2003).

\subsection{Board Committees and Earnings Management}

Vance (1983) argues that the audit committee, the compensation committee and the nomination committee all have significant influence on corporate activities while Klein (2003) argues that the overall composition of the board of directors has no influence on firm performance, but that the audit committee does. It is therefore likely that the structure of board committees and their composition will impact management's willingness to manage earnings. Xie et al. (2003) argue that the executive committee only plays an indirect role whereas the audit committee has a more direct role in controlling earnings management. 
Consequently, an active, well-structured and properly functioning audit committee may be able to reduce, if not eliminate, earnings management. It is therefore expected that professionally efficient audit committee members will play a significant role in preventing earnings management, and that an audit committee comprising a large proportion of independent directors will ensure effective monitoring. This expectation is in line with the recommendations of Levitt's Blue Ribbon Panel (Xie, et al., 2003). The Cadbury Report (Cadbury, 1992) also suggests that the audit and remuneration committee should be comprised mainly or entirely of non-executive directors.

\subsection{Auditor and Earnings Management}

Prior research also shows that auditor and audit quality play an important role regarding the control of earnings management (Balsam, Krishnan, \& Yang, 2003; Siregar \& Utama, 2008; Teoh \& Wong, 1993). They also argue that the Big 4 auditors have greater independence from the client as compared to non-Big 4 auditors. Companies audited by Big 4 firms have less discretionary accruals than others because the auditors play a significant role in constraining opportunistic earnings management behaviour. However, the auditor's ability to be independent is influenced by the incentives they receive, and a recent study has investigated whether non-audit services compromise auditor independence or whether the consequences are that the auditor allows pernicious earnings management (Cahan, Emanuel, Hay, \& Wong, 2008; Habib \& Islam, 2007).

\subsection{Ownership Concentration, Securities Exchange Listing and Earnings Management}

Management stockholding reduces agency conflicts because they are both a principal (since they are shareholders in their own right) and an agent (for the other shareholders). It is therefore expected that this dual role should result in a lower incidence of earnings management. Previous studies have found a negative relationship between management shareholding and the absolute value of abnormal accruals (Warfield, Wild, \& Wild, 1998). Healy (1985) found that CEOs tend to manage earnings to maximise their bonus while Klein (2002) found CEO shareholdings to be no predictor of earnings management. Institutional ownership provides wider monitoring and greater control of firm information and reduces earnings management (Hermes, Postma, \& Zivkov, 2007; Siregar \& Utama, 2008).

\section{Hypothesis Development}

Five hypotheses are developed in order to test the association between corporate governance and discretionary accruals.

\subsection{Regulations and Earnings Management}

The basic premise of capitalism is that individuals pursue their own interest (Smith, 1776). Appropriate corporate laws and regulations are vital for the efficient working of a capitalistic economy in order to maximise individual and national wealth. There is a widespread belief that only strict laws and regulatory controls can prevent management acting for their own self-interest (Drobietz, 2002). However, an appropriate legal structure may help to protect investors and their investments, and also ensures a 'proper' environment that generates a return on investment. Corporate governance regulations should lead to improved systems of internal control within companies. Leuz et al. (2003) examined systematic differences of earnings management and found a negative relationship between corporate governance 
regulations and the level of earnings management. Leuz et al. (2003) argue that insiders have incentives to conceal their private control benefits from outsiders.

Prior research also found that financial disclosure practices have a positive impact on investors' confidence, reduce information asymmetry and result in a lower cost of capital (Francis, et al., 2008). Similarly, corporate governance and other regulations help management to structure strong internal control systems and monitor shareholders' interests. Tightening rules and regulations and the adoption of self regulation by market participants are the result of the growing conviction that better corporate governance will deliver higher shareholder value (Bartle \& Vass, 2007; Drobietz, 2002). Increased regulation enhances strong corporate governance, and together with a more independent and effective board of directors and board committees, leads to a reduction in managerial discretionary decisions resulting in earnings manipulation. The first regulation-related hypothesis, expressed in the null form is therefore:

$H_{0} 1$ : There is no relationship between the presence of corporate governance regulations and discretionary accruals.

\subsection{Corporate Governance Compliance and Earnings Management}

An effective and efficient board of directors is the prime component in a system of corporate governance. However, if the board is dominated by executive directors, the opportunity to indulge in 'discretionary financial decisions' will be greater than if the board was dominated by independent directors. Similarly, CEO duality, where the CEO is also the chair of the board of directors, creates an environment that enables discretionary decisions concerning the management of earnings. It is suggested that the use of appropriate board committees such as an audit committee, remuneration committee, and a nomination committee, will act to reduce discretionary managerial decisions. For example, having at least one independent director with financial expertise on the audit committee will enhance the level of corporate governance, which, in turn, should reduce discretionary accruals. Similar arguments can be mounted for having independent directors on the remuneration committee (since they will then be able to rationalise the remuneration and incentives offered to management), and on the nomination committee (to remove the possibility of nepotistic appointments).

The results of empirical research suggest that outside directors are able to more effectively monitor and reduce agency costs, which results in lower discretionary accruals (Jiang, Lee, \& Anandarajan, 2008; Klein, 2002; Vance, 1983). Similarly, effective and independent board committees are expected to monitor internal control systems better. All of these attributes of best practice generally form part of a robust set of corporate governance regulations, so compliance with these regulations should strengthen the level of corporate governance. This leads to the following null hypothesis related to corporate governance compliance:

$H_{0} 2$ : There is no relationship between the level of compliance with corporate governance regulation and discretionary accruals.

\subsection{Control Shareholding and Earnings Management}

A zero-based agency cost indicates that the firm is owned by a single owner-manager. Agency costs exist when ownership is separated from management, i.e. when the manager holds less than 100 percent of the equity. Agency costs increase with the reduction in the proportion of managerial ownership. Companies that operate with a controlling shareholder have less independent decision-making compared to companies where there is no controlling 
shareholder, since the controlling shareholder has access to information and, by definition, controls the activities and decisions of the board of directors (Varma, Patel, \& Naidu, 2009).

Minority shareholders have little or no influence on board decisions, and may feel insecure when the corporate environment is not regulated. Independent management have better control over decision-making if the shareholding is scattered amongst many owners. Therefore, a non-mandatory corporate governance regulatory environment may not be sufficient to protect minority shareholders. This leads to the following null hypothesis concerning a controlling shareholder:

$H_{0} 3$ : There is no relationship between the presence of a controlling shareholder and discretionary accruals.

\subsection{Business Operation Tenure and Earnings Management}

A company operating in society is expected to have a robust system of internal control and to comply with relevant regulations (Kole \& Lehn, 1997). As discussed previously, effective systems of controlling and monitoring management lead to a reduction in discretionary accruals. It can be argued that a mature company that has been operating for a period of time will have such systems in place, and that its stakeholders will be actively monitoring the financial position of the business. This argument is supported, at least in part, by prior research which provides evidence that growing and newly established firms have more discretionary accruals than mature firms (McNichols \& Wilson, 1988; Shen \& Chih, 2007). However, all firms, irrespective of maturity, could manage their earnings - for example, Dechow \& Dichev (2002) show that longer operating cycles generate greater uncertainty, give rise to more estimation errors, and result in lower quality of accruals. Thus the evidence regarding the relationship between the maturity of the company and earnings management is mixed. The current research will provide further evidence about this relationship, so the fourth null hypothesis is as follows:

$H_{0} 4$ : There is no relationship between business operating tenure and discretionary accruals.

\subsection{Listing Tenure and Earnings Management}

The New Zealand Stock Exchange Listing Rules and the Corporate Governance Best Practice Code 2004 ("New Zealand Corporate Governance Best Practice Code," 2004) both provide criteria with which listed companies must or should (respectively) comply. Compliance with these criteria should result in an environment whereby opportunities for earnings management will be limited. It is therefore expected that the longer a company has been listed, the more likely they will have a lower level of discretionary accruals. Hypothesis five, expressed in the null form, is therefore:

$H_{0} 5$ : There is no relationship between the listing tenure of a company and discretionary accruals.

In essence, this hypothesis posits that a regulated environment of corporate governance will reduce discretionary accruals by imposing more accountable and effective monitoring systems.

\section{Sample}

The sample of companies for this study is selected from companies listed by the New Zealand Stock Exchange Limited (NZX). The NZX comprises two markets: the New Zealand 
Stock Market (NZSE), the main board where premium equities are traded, and the New Zealand Alternative Market (NZAX) which lists companies that are comparatively new and, typically, in a rapid growth phase. The latter market allows these young companies to issue equities comparatively cheaply as compared to the main board. It should be noted that corporate governance research in New Zealand has not previously included the NZAX companies because this board is a recent addition to the market. The inclusion of the NZAX should therefore add depth to the previous studies of corporate governance in New Zealand.

The sample period covers the years from 2000 to 2007, inclusive. To be included in the sample, companies must have operated over the entire period of the study. By the end of August, 2008 a total of 153 companies were listed by NZX. Consistent with previous research, twenty nine finance companies were excluded since they are subject to different regulations and reporting procedures. Thirty five companies did not provide a complete set of financial reports usable for this research while financial information about nineteen companies was not available.

Corporate governance information such as the composition of the board of directors, the board committees, and audit information was collected manually from IRG Ltd's deep archive section while financial data was collected from DATASTREAM. Company websites also provided information about operating cycles and the length of time that the company had been listed on the stock exchange. The final sample of seventy companies was then divided into different industry sectors using the NZX categories in Table 1, as follows:

Table 1

Sector Composition of Sample

\begin{tabular}{|l|c|c|c|}
\hline \multicolumn{1}{|c|}{ Sector Group } & Companies & Observation & Percentage \\
\hline Energy & 8 & 64 & $11.43 \%$ \\
\hline Goods & 11 & 88 & $15.71 \%$ \\
\hline Investment & 5 & 40 & $7.14 \%$ \\
\hline Primary & 9 & 72 & $12.86 \%$ \\
\hline Property & 5 & 40 & $7.14 \%$ \\
\hline Service & 32 & 256 & $45.72 \%$ \\
\hline Total & 70 & 560 & $100 \%$ \\
\hline
\end{tabular}

\section{Research Methodology}

This section describes the research methodology, including the measurement of the research variables and the statistical techniques and other models used in this research.

\subsection{Measurement of Variables}

This section describes how the dependent and independent variables were measured and how discretionary accruals were calculated.

\subsubsection{MEASURE OF DEPENDENT VARIABLE}

Discretionary accruals were measured using Jones Model (Jones, 1991), the Modified Jones Model (1995) and the Performance Matched Model (Kothari et al, 2005). Free cash flow was used to measure the performance matched model as follows:

where:

$$
\frac{N D A_{i t}}{A_{i t-1}}=\alpha_{0}+\alpha_{1}\left[\frac{1}{A_{i t-1}}\right]+\beta_{1 i}\left[\frac{\Delta R E V_{i t}-\Delta A R_{i t}}{A_{i t-1}}\right]+\beta_{2}\left[\frac{P P E_{i t}}{A_{i t-1}}\right]+\delta_{1} R O A_{i t-1}
$$


$N D A_{i t}$ (non-discretionary accruals) is divided by $A_{i t-1}$ (total assets in year t- 1 for firm $i$ ) (

Total Accruals $=$ Net Income before extraordinary items less Free Cash Flow which includes cash flow from operating activities and cash flow from investing activities

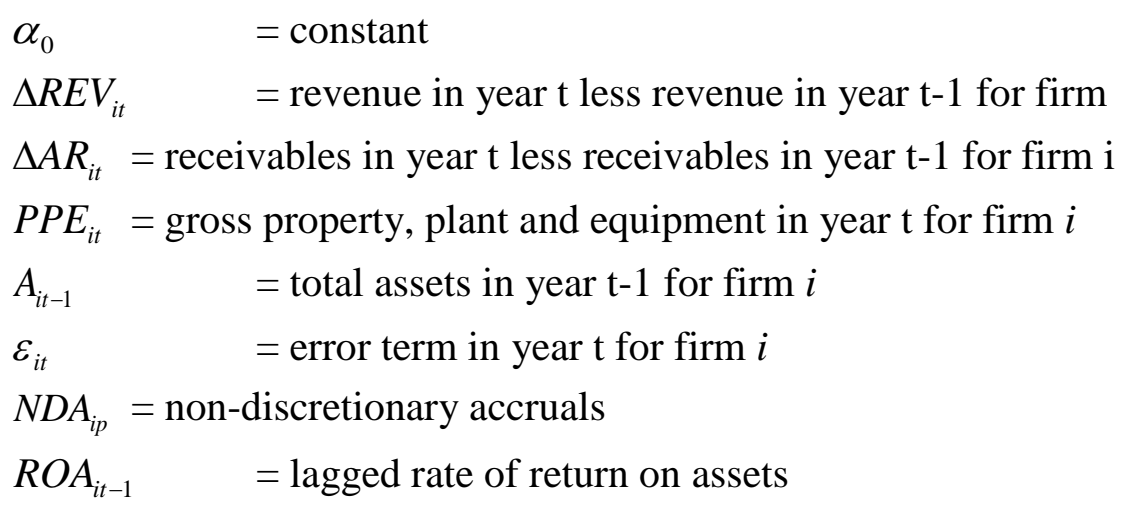

\subsubsection{MEASURE OF INDEPENDENT VARIABLES}

In this research regulation, corporate governance index, control shareholding, NZX listing tenure, and operating tenure are independent variables that are explained as follows.

\subsubsection{Regulation}

The regulation effect will be measured by a dummy variable since it is anticipated that corporate governance regulations will enhance corporate governance compliance and reduce opportunistic behaviour of management. The opportunistic behaviour of management is indicated by discretionary accruals, therefore for the years 2000-2003, the regulation dummy variable will be ' 0 ' to indicate the existence of discretionary accruals when there were no regulations, otherwise the regulation dummy variable will be ' 1 '. It is expected that there will be a negative correlation between the regulation dummy variable and discretionary accruals.

\subsubsection{Corporate Governance Index}

Corporate governance mechanism consists of a complex set of interrelationships so using a single factor or variable to measure corporate governance is challenging. Researchers tend to examine the overall impact of a much broader corporate governance mechanism by formulating a corporate governance index (CGI) and rating systems (Berghe \& Levrau, 2004; Strenger, 2004). In this study, the index accumulates all aspects of corporate governance including board of directors' attributes, external auditor, supervisory committees, management shareholdings, and listing tenure of firms. The index is calculated as:

where:

$$
C G I_{i t}=\frac{\sum C V C G_{i t}}{\sum M P V C G C_{i t}} x 100 \ldots \ldots .
$$

$\mathrm{CGI}_{i t} \quad=$ Corporate governance index for firm $i$ in year $t$;

$\mathrm{CVCG}_{\text {it }} \quad=$ Cumulative value of corporate governance for firm $i$ in year $t$;

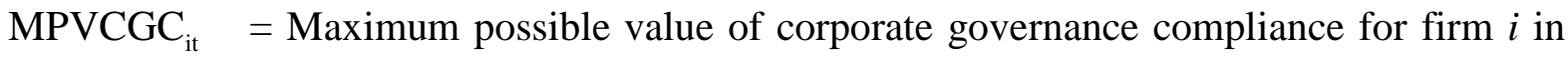
year $t$;

The corporate governance index is a composite measurement based on dichotomous variables and actual values measured (Lara, Osmab, \& Penalvac, 2007; Larcker \& 
Richardson, 2004; Larcker, Richardson, \& Irem, 2005). A CGI is prepared using twenty indicators as follows in Table 2.

Table 2

Measure of Corporate Governance Index

\begin{tabular}{|c|c|}
\hline \multicolumn{2}{|l|}{ Board of Director Score } \\
\hline No of director & $\begin{array}{l}\text { This variable is assigned a value of } 1 \text { if the number of directors is not less than } \\
\text { the median, and } 0 \text { otherwise. }\end{array}$ \\
\hline Board Independence & $\begin{array}{l}\text { This variable is assigned a value of } 1 \text { if the ratio of independent directors is not } \\
\text { less than the median, and } 0 \text { otherwise }\end{array}$ \\
\hline Board Tenure & $\begin{array}{l}\text { This variable is assigned a value of } 1 \text { if the combined tenure (in years) of all } \\
\text { directors in the sample company exceeds the median, otherwise the value is } 0 \text {. }\end{array}$ \\
\hline Busy Board & $\begin{array}{l}\text { This variable is assigned a value of } 0 \text { if the total outside directorships is greater } \\
\text { than median, otherwise the value is } 1 .\end{array}$ \\
\hline Board Meeting & $\begin{array}{l}\text { This variable is assigned the value of } 0 \text { if the number of board meetings was } \\
\text { less than the median, otherwise the value is } 1 \text {. }\end{array}$ \\
\hline CEO duality & $\begin{array}{l}\text { This variable is assigned the value of } 0 \text { where the CEO has this dual role, } 1 \\
\text { otherwise. }\end{array}$ \\
\hline CEO Experience & $\begin{array}{l}\text { This variable is assigned the value of } 1 \text { if the CEO has not less than the median } \\
\text { number of years of experience and } 0 \text { otherwise. }\end{array}$ \\
\hline \multicolumn{2}{|l|}{ Board Committee Score } \\
\hline No of board committee & Companies that have all three board committees are coded 1, 0 otherwise \\
\hline Audit committee size & $\begin{array}{l}\text { This variable is assigned the value of } 1 \text { if the audit committee was not smaller } \\
\text { than the median, } 0 \text { otherwise }\end{array}$ \\
\hline $\begin{array}{l}\text { Audit committee financial } \\
\text { expertise }\end{array}$ & $\begin{array}{l}\text { This variable was assigned the value of } 1 \text { if the company followed this } \\
\text { recommendation, } 0 \text { otherwise. }\end{array}$ \\
\hline Audit committee meeting & $\begin{array}{l}\text { This variable is assigned the value of } 0 \text { if the audit committee met less } \\
\text { frequently than the median and } 1 \text { otherwise }\end{array}$ \\
\hline $\begin{array}{l}\text { Audit committee } \\
\text { experience }\end{array}$ & $\begin{array}{l}\text { This variable is assigned a value of } 1 \text { if the experience of the audit committee } \\
\text { was not less than the median, and } 0 \text { otherwise. }\end{array}$ \\
\hline Chair of audit committee & $\begin{array}{l}\text { This variable is assigned a value of } 0 \text { if the same person was appointed as chair } \\
\text { of both committees, and } 1 \text { otherwise. }\end{array}$ \\
\hline $\begin{array}{l}\text { Independent director in } \\
\text { audit committee }\end{array}$ & $\begin{array}{l}\text { This variable was assigned a value of } 0 \text { if the number of independent directors } \\
\text { on the audit committee is less than the median, and } 1 \text { otherwise. }\end{array}$ \\
\hline $\begin{array}{l}\text { Independent director ratio } \\
\text { in nomination committee }\end{array}$ & $\begin{array}{l}\text { This variable is assigned a value of } 0 \text { if the ratio of independent directors on the } \\
\text { audit committee is less than the median, and } 1 \text { otherwise. }\end{array}$ \\
\hline \multicolumn{2}{|l|}{ Audit Score } \\
\hline Big 4 & $\begin{array}{l}\text { This variable is therefore assigned a value of } 1 \text { if the company is audited by a } \\
\text { 'Big 4' firm, and } 0 \text { otherwise }\end{array}$ \\
\hline Auditor tenure & $\begin{array}{l}\text { This variable is therefore assigned a value of } 0 \text { if the company is audited by the } \\
\text { same auditor for more than five years and } 1 \text { otherwise }\end{array}$ \\
\hline $\begin{array}{l}\text { Ratio of audit fee and non- } \\
\text { audit fee }\end{array}$ & $\begin{array}{l}\text { This variable is assigned a value of } 0 \text { if the ratio of fees paid to the auditors is } \\
\text { more than the median, and } 1 \text { otherwise }\end{array}$ \\
\hline \multicolumn{2}{|c|}{ Director shareholding and Listing Score } \\
\hline Director shareholdings & $\begin{array}{l}\text { This variable is assigned a value of } 1 \text { if the company is also listed on an } \\
\text { overseas stock exchange and } 0 \text { otherwise }\end{array}$ \\
\hline Dual listing status & $\begin{array}{l}\text { The variable is assigned a value of } 0 \text { if the proportion of director shareholding is } \\
\text { greater than the median, otherwise the value is } 1 .\end{array}$ \\
\hline
\end{tabular}

\subsubsection{Control Shareholding}

If one entity holds at least half of the issued shares, they are considered to have the controlling shareholding of the company. Companies having a more concentrated ownership are more likely to have higher discretionary accruals as compared to companies with less concentrated ownership. The controlling shareholder has access to more information and, by 
definition, can control the company's governance processes and internal control systems. This variable will be coded ' 1 ' if the company has a controlling shareholder and ' 0 ' otherwise. It is expected that there will be a positive relationship between this variable and discretionary accruals.

\subsubsection{NZX Listing Tenure}

Companies that are listed on the stock exchange are subject to higher monitoring by investors and regulators. It is expected that all stakeholders would access news releases from the company as and when they occur, which suggests that it would be more difficult for such companies to have discretionary accruals. It is posited that the longer a company has been listed, the less likelihood there will be discretionary accruals. It is expected that there will be a negative relationship between this variable and discretionary accruals.

\subsubsection{Operating Tenure}

Company operating age and discretionary accruals have an inconclusive relationship. Older companies are expected to have stable internal control mechanisms which should lead to lower discretionary accruals. However, a company that is in the early phase of its life is always likely to have more discretionary accruals than a mature company. Thus it is posited that as the age of business operation increases the possibility of discretionary accruals decreases. On the other hand, it can be argued that companies that have been in the market for a long time may not be too concerned about the reaction of the market to news about the existence of discretionary accruals. In this case there would be a positive association between the age of the company and discretionary accruals.

\subsubsection{MEASUREMENT OF CONTROL VARIABLES}

In this study, leverage, return on assets (ROA), and firm size are considered to be control variables.

\subsubsection{Leverage}

Leverage indicates business risk in terms of external financing. A company with more leverage indicates higher debt contribution in terms of its financial structure. A firm that has higher leverage is more likely to have higher discretionary accruals in order to manage their external financing and to show a better asset structure with higher revenue performance. Leverage is therefore considered a control variable in the multivariate equation (Bradbury, Mak, \& Tan, 2006).

\subsubsection{Return on Assets}

Return on assets is the indicator of financial performance of an organisation as it reflects how effectively and efficiently the resources are being utilised. It is expected that companies with higher ROA have lower discretionary accruals, and that there will be a negative relationship with discretionary accruals.

\subsubsection{Firm Size}


Controlling for firm size is common in earnings management research. It is expected that a large firm will have relatively higher discretionary accruals compared to a small firm since a large firm generally will have diversified or decentralised management decision-making. A diversified decision-making process leads to higher discretionary accruals for business. It is expected that there is a positive relationship between firm size and discretionary accruals.

\subsubsection{SECTOR DUMMY MEASURE}

To evaluate the business sector effect, a sector dummy variable was considered to be relevant. Following the NZX index categories, sample companies are divided into 6 different sectors to obtain representative samples for each sector. The sectors are: service, primary, energy, goods, property and investment. while the service sector is used as the intercept for regression analysis to avoid the dummy variable trap (Gujarati, 2003). Information existing on the same sector is categorised as ' 1 ' and otherwise ' 0 ' for sector dummy.

\subsection{Multivariate Regression Model}

Considering all the above explanatory variables the following general multivariate regression model is prepared:

$$
\begin{aligned}
& \text { DAC }_{i t}=\varphi_{1}+\varphi_{2} \operatorname{Re} g_{-} \text {Dummy }_{i t}+\varphi_{3} \text { CGI }_{i t}+\varphi_{4}\left(C G I_{i t} * \operatorname{Re} g_{-} \text {Dummy }_{i t}\right)+ \\
& \varphi_{5} \text { ContShr }_{i t}+\varphi_{6} \text { NZXListingTen }_{i t}+\varphi_{7} \text { OperatingTen }_{i t}+\varphi_{8} \text { Leverage }_{i t}+\varphi_{9} R O A_{i t}+ \\
& \varphi_{10} T A_{i t-1}+\varphi_{11} \sum_{11}^{15} \text { Sector_Dummy }_{i t}+\xi_{i t} \ldots . . .(3)
\end{aligned}
$$

where:

$$
\begin{aligned}
& D A C_{i t} \quad=\text { Discretionary Accruals (Jones Model, Modified Jones Model, } \\
& \text { Performance Matched Model, Performance Matched Free Cash } \\
& \text { Flow Model); } \\
& \text { Re } g_{-} \text {Dummy }_{i t} \quad \text { = Regulation Dummy; } \\
& \text { CGI }_{t} \quad=\text { Corporate Governance Index in year } \mathrm{t} \text {; } \\
& \text { ContShr }_{t} \quad=\text { Control Shareholding in year } \mathrm{t} \text {; } \\
& \text { NZXListTen }_{t} \quad \text { = NZX Listing Tenure in year } \mathrm{t} \text {; } \\
& \text { OperatingTen }_{t} \quad=\text { Operating Tenure in year } \mathrm{t} \text {; } \\
& \text { Leverage }_{t} \quad=\text { Leverage in year } \mathrm{t} \text {; } \\
& \mathrm{ROA}_{t} \quad=\text { Return on Assets in year } \mathrm{t} \text {; } \\
& T A_{t-1} \quad=\text { Total Assets in year (t-1) as a proxy of firm size; } \\
& \sum_{1}^{5} \text { Sector_Dummy }_{t}=\text { Sector Dummy for } 1,2 \ldots 5 \text {; } \\
& \varphi \quad=\text { Coefficient of respective variables } 1,2 \ldots 15 \text {; } \\
& \xi \quad=\text { Error term. }
\end{aligned}
$$

This model is used for all the measurements of discretionary accruals calculation in the next section. Discretionary accruals are the dependent variable used to measure managerial opportunistic behaviour impact on earnings.

\section{Results}


The objective of this paper was to investigate the effect of corporate governance regulations on managerial accruals (discretionary accruals) in New Zealand listed companies. First the results of descriptive statistics are presented then, in the following sections, results of correlation analysis,; abnormal accruals and multivariate analysis are illustrated.

\subsection{Descriptive Statistics}

The descriptive statistics for the key variables are presented in Table 3. This table shows a descriptive analysis pre and post regulation, including the total sample of different variables. Average discretionary accruals for the Jones Model, Modified Jones Model, Performance Matched Model and Performance Matched Free Cash Flow Model are close to zero, implying that the average descriptive statistics of discretionary accruals did not provide any sensible evidence to conclude. Total accruals were mainly captured by sales and fixed assets like property plant and equipment scaling. Discretionary accruals are captured on the unexplained variable of the regression with descriptive statistics evidenced with the value consistent in all the models of accrual measure. Average corporate governance compliance increased from 0.52 to 0.55 as a result of regulatory impact. The average operating tenure of business is 28 years whereas average listing tenure, significantly less at 12 years, implies that firms take time to list on the stock exchange after incorporation. The average listing years indicates that firms listed in the capital market at the growth level of business.

\subsection{Correlation Analysis}

Correlation analysis is conducted to find the relationship strength among independent and dependent variables. Table 4, the Correlation Matrix, shows all the models of total accruals measurement and independent variable relationships. None of the independent variables have steady unique correlation with discretionary accruals in all models. The Jones model has significant correlation with the corporate governance index ( $r=-0.079$ at the $10 \%$ level) and return on assets ( $r=0.323$, at the $1 \%$ level). The modified Jones model is correlated with the same variables as corporate governance index ( $r=-0.087)$ with $5 \%$ level of significance and return on assets $(r=0.369)$ with $1 \%$ level of significance. In both cases, the corporate governance index has a negative relationship with discretionary accruals, indicating that better corporate governance practice reduces discretionary accruals as a proxy of earnings management.

Companies' performance as ROA having a positive relationship with discretionary accruals indicates that higher performing companies show statistically significant higher discretionary accruals. McNichols (2000) also claims that Jones and Modified Jones Models of discretionary accruals have positive relationships with ROA. The performance matched discretionary accruals model is correlated with business operating tenure $(r=-0.108)$ only. Finally, the free cash flow discretionary accruals model correlated with the corporate governance index ( $r=-0.109)$, business operating tenure $(r=0.216)$, leverage $(r=-0.124)$ and primary sector $(r=0.126)$ at $5 \%$ level of significance. The correlation coefficient is checked for higher collinearity among regressors. It can be seen from the correlation matrix that there is no high correlation among variables. As a result, collinearity is no threat to the independence of regression reported in the following sections. 
Table 3

Descriptive Analysis

\begin{tabular}{|c|c|c|c|c|c|c|c|c|c|}
\hline \multirow[t]{2}{*}{ Details } & \multicolumn{3}{|c|}{ Mean } & \multicolumn{3}{|c|}{ Median } & \multicolumn{3}{|c|}{ Standard Deviation } \\
\hline & $\begin{array}{c}\text { Pre- } \\
\text { Regulation } \\
\end{array}$ & $\begin{array}{c}\text { Post- } \\
\text { Regulation }\end{array}$ & $\begin{array}{c}\text { All } \\
\text { Sample } \\
\end{array}$ & $\begin{array}{c}\text { Pre- } \\
\text { Regulation }\end{array}$ & $\begin{array}{c}\text { Post- } \\
\text { Regulation }\end{array}$ & $\begin{array}{c}\text { All } \\
\text { Sample }\end{array}$ & $\begin{array}{c}\text { Pre- } \\
\text { Regulation }\end{array}$ & $\begin{array}{c}\text { Post- } \\
\text { Regulation }\end{array}$ & $\begin{array}{c}\text { All } \\
\text { Sample } \\
\end{array}$ \\
\hline Discretionary Accruals - Jones Model & -0.001 & 0.001 & 0.001 & 0.006 & 0.019 & 0.012 & 0.268 & 0.141 & 0.214 \\
\hline $\begin{array}{l}\text { Discretionary Accruals - Modified } \\
\text { Jones Model }\end{array}$ & -0.005 & 0.018 & 0.00648 & 0.007 & 0.018 & 0.0136 & 0.278 & 0.140 & 0.22053 \\
\hline $\begin{array}{l}\text { Discretionary Accruals - Performance } \\
\text { Matched Model }\end{array}$ & 0.001 & 0.000 & 0.000 & -0.009 & 0.002 & -0.00385 & 0.196 & 0.122 & 0.16268 \\
\hline $\begin{array}{l}\text { Discretionary Accruals - Performance } \\
\text { Matched Free Cash Flow Model }\end{array}$ & 0.001 & 0.000 & 0.000 & 0.099 & 0.178 & 0.141 & 1.800 & 1.666 & 1.733 \\
\hline Regulation Dummy & 0.000 & 1.000 & 0.5 & 0.000 & 1.000 & 0.5 & 0.000 & 0.000 & 0.5 \\
\hline Corporate Governance Index (CGI) & 0.519 & 0.554 & 0.536 & 0.500 & 0.550 & 0.5 & 0.120 & 0.126 & 0.124 \\
\hline CGI * Regulation Dummy & 0.000 & 0.554 & 0.277 & 0.000 & 0.550 & 0.15 & 0.000 & 0.126 & 0.291 \\
\hline Listing Tenure & 12.057 & 16.046 & 14.052 & 8.000 & 12.000 & 10 & 11.505 & 11.558 & 11.693 \\
\hline Operating Tenure & 28.700 & 32.707 & 30.704 & 16.000 & 20.000 & 18 & 34.265 & 34.261 & 34.291 \\
\hline Return on Assets & 0.058 & 0.087 & 0.072 & 0.096 & 0.100 & 0.099 & 0.426 & 0.321 & 0.377 \\
\hline Total Assets (t-1) & 2706993 & 1741694 & 2224343 & 120109 & 192802 & 145571.5 & 18895582 & 6008815 & 14016282 \\
\hline Primary Sector & 0.000 & 0.157 & 0.079 & 0.000 & 0.000 & 0.000 & 0.000 & 0.365 & 0.269 \\
\hline Energy Sector & 0.000 & 0.129 & 0.064 & 0.000 & 0.000 & 0.000 & 0.000 & 0.335 & 0.245 \\
\hline Goods Sector & 0.000 & 0.071 & 0.036 & 0.000 & 0.000 & 0.000 & 0.000 & 0.258 & 0.186 \\
\hline Property Sector & 0.000 & 0.114 & 0.057 & 0.000 & 0.000 & 0.000 & 0.000 & 0.319 & 0.232 \\
\hline Investment Sector & 0.000 & 0.071 & 0.036 & 0.000 & 0.000 & 0.000 & 0.000 & 0.258 & 0.186 \\
\hline
\end{tabular}


Table 4

Correlation Matrix

\begin{tabular}{|c|c|c|c|c|c|c|c|c|c|c|c|c|c|c|c|c|c|c|}
\hline Variables & 1 & 2 & 3 & 4 & 5 & 6 & 7 & 8 & 9 & 10 & 11 & 12 & 13 & 14 & 15 & 16 & 17 & 18 \\
\hline $\begin{array}{l}\text { Jones Discretionary } \\
\text { Accruals (1) }\end{array}$ & 1 & $0.987^{* *}$ & 0.745 & $-0.201^{*}$ & 0.062 & $-0.079 *$ & 0.051 & -.007 & 0.032 & -0.002 & -0.028 & $.323 * *$ & 0.010 & -0.024 & 0.014 & 0.017 & 0.036 & -0.012 \\
\hline $\begin{array}{l}\text { Modified Jones } \\
\text { Discretionary } \\
\text { Accruals (2) }\end{array}$ & & 1 & $.738^{* *}$ & $-.191^{* *}$ & 0.054 & $-.087 *$ & 0.043 & -0.016 & 0.024 & 0 & 0.02 & $.369 * *$ & 0.01 & 0.022 & 0.014 & 0.017 & 0.039 & -0.004 \\
\hline $\begin{array}{l}\text { Performance Matched } \\
\text { Discretionary } \\
\text { Accruals (3) }\end{array}$ & & & 1 & $-.259 * *$ & 0.00 & -0.026 & -0.01 & -0.028 & 0.013 & $-.108 *$ & 0.042 & 0.005 & -0.019 & 0.039 & -0.035 & -0.02 & -0.036 & 0.032 \\
\hline $\begin{array}{l}\text { Free Cash Flow } \\
\text { Discretionary } \\
\text { Accruals (4) }\end{array}$ & & & & 1 & 0.00 & $-.109 * *$ & -0.032 & 0.043 & 0.018 & $.216^{* *}$ & $-.124 * *$ & -0.009 & 0.016 & $.126^{* *}$ & 0.033 & 0.000 & -0.001 & 0.064 \\
\hline $\begin{array}{l}\text { Regulation Dummy } \\
\text { (5) }\end{array}$ & & & & & 1 & $.140^{* *}$ & $.952^{* *}$ & 0.028 & $.171^{* *}$ & 0.058 & 0.062 & 0.039 & -0.034 & 0.000 & 0.000 & 0.000 & 0.000 & 0.000 \\
\hline $\begin{array}{l}\text { Corporate Governance } \\
\text { Index (6) }\end{array}$ & & & & & & 1 & $.351^{* *}$ & 0.005 & $.119 * *$ & $.089 *$ & 0.002 & $-.163^{* *}$ & -0.002 & $-.152^{* *}$ & $.116^{* *}$ & $-.084^{*}$ & $-.184 * *$ & $-.171^{* *}$ \\
\hline $\begin{array}{l}\text { Interaction of CGI and } \\
\text { REGDUMMY (7) }\end{array}$ & & & & & & & 1 & 0.026 & $.182 * *$ & 0.072 & 0.031 & 0.015 & -0.04 & -0.026 & 0.027 & -0.01 & -0.041 & -0.036 \\
\hline $\begin{array}{l}\text { Controlling } \\
\text { Shareholdings (8) }\end{array}$ & & & & & & & & 1 & $-.108^{*}$ & 0.021 & $-.151^{* *}$ & -0.028 & $.097 *$ & $-.089 *$ & $-.104 *$ & $-.108^{*}$ & $.183^{* *}$ & $-.170^{* *}$ \\
\hline $\begin{array}{l}\text { NZX Listing Tenure } \\
\text { (9) }\end{array}$ & & & & & & & & & 1 & $.258 * *$ & -0.052 & -0.045 & $-.095^{*}$ & 0.063 & 0.053 & -0.004 & -0.009 & -0.004 \\
\hline $\begin{array}{l}\text { Business Operating } \\
\text { Tenure (10) }\end{array}$ & & & & & & & & & & 1 & $-.164 * *$ & 0.043 & $.112 * *$ & $-.180 * *$ & $.214^{* *}$ & $-.113^{* *}$ & 0.023 & $-.112^{* *}$ \\
\hline Leverage (11) & & & & & & & & & & & 1 & 0.021 & -0.025 & -0.056 & -0.038 & -0.045 & $.176^{* *}$ & -0.012 \\
\hline Return On Assets (12) & & & & & & & & & & & & 1 & 0.014 & $-.095 *$ & 0.067 & 0.064 & $.149 * *$ & 0.037 \\
\hline Total Assets (13) & & & & & & & & & & & & & 1 & -0.053 & $.160^{* *}$ & -0.02 & $\begin{array}{l}-0.015 \\
\end{array}$ & -0.027 \\
\hline Primary Sector (14) & & & & & & & & & & & & & & 1 & $-.166^{* *}$ & $-.120 * *$ & $-.155^{* *}$ & $-.120 * *$ \\
\hline Energy Sector (15) & & & & & & & & & & & & & & & 1 & $-.107^{*}$ & $\begin{array}{l}-.138 * * \\
\end{array}$ & $-.107^{*}$ \\
\hline Goods Sector (16) & & & & & & & & & & & & & & & & 1 & $\begin{array}{l}.100 * \\
\end{array}$ & -0.077 \\
\hline Property Sector (17) & & & & & & & & & & & & & & & & & 1 & $-.100^{*}$ \\
\hline $\begin{array}{l}\text { Investment Sector } \\
\text { (18) }\end{array}$ & & & & & & & & & & & & & & & & & & 1 \\
\hline
\end{tabular}

*** Correlation is significant at the 0.01 level (2-tailed)

** Correlation is significant at the 0.05 level (2-tailed) 


\subsection{Abnormal Accruals}

This section explains the overall accruals measurement and explanatory power of Performance Matched Free Cash Flow Model. Three other established accruals measurement models are also calculated to compare with our model (Performance Matched Free Cash Flow Model) in explaining coefficients. Table 5 shows the explanatory power of all models.

Table 5

Coefficient of Accruals Model

\begin{tabular}{|c|c|c|c|c|c|c|}
\hline Models & $\begin{array}{c}\text { Adjusted } \\
\qquad \mathbf{R}^{2}\end{array}$ & Intercept & $\begin{array}{l}\text { Total Assets } \\
\text { Reciprocal }\end{array}$ & $\begin{array}{c}\text { Revenue } \\
\text { Coefficient }\end{array}$ & $\begin{array}{c}\text { Property } \\
\text { Plant and } \\
\text { Equipment } \\
\text { Coefficient } \\
\end{array}$ & $\begin{array}{c}\text { ROA } \\
\text { coefficient }\end{array}$ \\
\hline Jones Model & $\begin{array}{c}0.204 \\
(48.861)^{* * *}\end{array}$ & $\begin{array}{c}-922.871 \\
(-8.856)^{* * *} \\
\end{array}$ & $\begin{array}{c}0.03 \\
(8.974)^{* * *} \\
\end{array}$ & $\begin{array}{c}0.019 \\
(1.803)^{* *}\end{array}$ & - & - \\
\hline $\begin{array}{l}\text { Modified } \\
\text { Jones Model }\end{array}$ & $\begin{array}{c}0.201 \\
(48.014)^{* * *}\end{array}$ & $\begin{array}{l}-925.144 \\
(-8.859)^{* * *}\end{array}$ & $\begin{array}{c}0.03 \\
(8.840)^{* * *}\end{array}$ & $\begin{array}{c}0.02 \\
(1.880)^{* *}\end{array}$ & - & - \\
\hline $\begin{array}{l}\text { Performance } \\
\text { Matched } \\
\text { Model } \\
\end{array}$ & $\begin{array}{c}0.316 \\
(65.429)^{* * *}\end{array}$ & $\begin{array}{c}0.025 \\
(1.846)^{*}\end{array}$ & $\begin{array}{c}-859.579 \\
(-8.578)^{* * *}\end{array}$ & $\begin{array}{c}0.029 \\
(9.298)^{* * *}\end{array}$ & $\begin{array}{c}-0.034 \\
(-2.688)^{* *}\end{array}$ & $\begin{array}{c}0.282 \\
(9.592)^{* * *}\end{array}$ \\
\hline $\begin{array}{l}\text { Performance } \\
\text { Matched Free } \\
\text { Cash Flow } \\
\text { Model }\end{array}$ & $\begin{array}{c}0.228 \\
(42.193)^{* * *}\end{array}$ & $\begin{array}{c}-0.355 \\
(-3.121)^{* *}\end{array}$ & $\begin{array}{l}-8762.579 \\
(-10.223)^{* * *}\end{array}$ & $\begin{array}{c}0.006 \\
(0.239)^{*}\end{array}$ & $\begin{array}{c}-0.008 \\
(-0.072)\end{array}$ & ${ }_{(6.792)^{* * *}}$ \\
\hline
\end{tabular}

* Correlation significant at the 0.10 level (2-tailed)

** Correlation significant at the 0.05 level (2-tailed)

*** Correlation significant at the 0.01 level (2-tailed)

Table 5 shows that the Jones Model (1991) and Modified Jones Model (1995) both have almost 20\% explanatory power at the $1 \%$ significant level. Moreover, all the determinants are statistically significant as total assets reciprocals and revenue coefficients. The Performance Matched Model (2005) has 31.6\% explanatory power at 1\% level of significance. The determinants of the performance matched model; total assets reciprocal, revenue coefficient, property plant and equipment coefficient and ROA coefficients are statistically significant. Finally, the performance matched free cash flow model has $22.8 \%$ explanatory power with $1 \%$ level of significance. Performance Matched Free Cash Flow Model determinants such as total assets reciprocal, revenue coefficient and ROA coefficient, are statistically significant, except property plant and equipment that is significant at more than the $10 \%$ level.

Table 6 shows the signs of regression for each of the variables in all models. Following basic accrual measurement process, revenue and fixed assets measurement is the key to calculating non-discretionary accruals. The coefficient of change in sales is positive because the sales of a profitable firm exceed its expenses and the net working capital will be positive if the credit policies of the firm and suppliers are similar. Conversely the coefficient on property, plant and equipment is negative because it determines the depreciation expenses (Ronen \& Yaari, 2007). 
Table6

Regressor's Sign \& Coefficients on each of the Model and Variables

\begin{tabular}{|c|c|c|c|c|c|}
\hline Details & $\begin{array}{l}\text { Expected } \\
\text { Sign }\end{array}$ & Jones Model & $\begin{array}{l}\text { Modified Jones } \\
\text { Model }\end{array}$ & $\begin{array}{l}\text { Performance } \\
\text { Matched } \\
\text { Model }\end{array}$ & $\begin{array}{c}\text { Performance } \\
\text { Matched Free } \\
\text { Cash Flow } \\
\text { Model }\end{array}$ \\
\hline $\begin{array}{l}\text { Total } \\
\text { Accruals }\end{array}$ & $+/-$ & $\begin{array}{l}\text { (Positive: 222; } \\
\text { Negative: 338) }\end{array}$ & $\begin{array}{l}\text { (Positive: 218; } \\
\text { Negative: 342) }\end{array}$ & $\begin{array}{l}\text { (Positive: 219; } \\
\text { Negative: 341) }\end{array}$ & $\begin{array}{l}\text { (Positive: 270; } \\
\text { Negative: 290) }\end{array}$ \\
\hline $\begin{array}{l}\text { Reciprocals of } \\
\text { Assets } \\
\text { Coefficient } \\
\end{array}$ & $?$ & - & - & - & - \\
\hline $\begin{array}{l}\text { Revenue \& } \\
\text { Receivables } \\
\text { Coefficient }\end{array}$ & + & $\begin{array}{c}\text { +(Positive: } 390 \\
\text { Negative:170) } \\
\text { =30.36\% }\end{array}$ & $\begin{array}{c}\text { +(Positive: 409; } \\
\text { Negative:151) } \\
\text { =26.96\% }\end{array}$ & $\begin{array}{c}\text { + (Positive: 391; } \\
\text { Negative:169) } \\
\text { = } \mathbf{3 0 . 1 8 \%}\end{array}$ & $\begin{array}{c}\text { +(Positive: } 390 ; \\
\text { Negative: } 170) \\
\text { = } \mathbf{3 0 . 3 6 \%}\end{array}$ \\
\hline $\begin{array}{l}\text { Property, } \\
\text { Plant and } \\
\text { Equipment } \\
\text { Coefficient }\end{array}$ & - & + & + & - & - \\
\hline $\begin{array}{l}\text { Performance } \\
\text { Indicator } \\
\text { (ROA) } \\
\text { coefficient } \\
\end{array}$ & $?$ & Not Applicable & Not Applicable & $\begin{array}{l}\text { + (Positive: } 458 ; \\
\text { Negative: } 102 \text { ) } \\
\text { = } 18.21 \%\end{array}$ & $\begin{array}{c}\text { +(Positive: } 458 ; \\
\text { Negative: } 102) \\
\quad=18.21 \%\end{array}$ \\
\hline
\end{tabular}

Table 6 shows that $30.36 \%$ of individual regressors (revenue receivables coefficient -ve 170) have negative values in the Jones Model and the overall coefficient is positive as expected, whereas Jones (1991) found in 39\% of the regressions the coefficient of change in sales is negative. Similarly, the Modified Jones Model (1995) has 26.96\% and the Performance Matched Model(S.P. Kothari, et al., 2005) has 30.18\% negative change in sales coefficients. The Performance Matched Free Cash Flow Model also shows 30.36\% of sales coefficients are negative, which is comparatively stronger than the Jones Model, Modified Jones Model and Performance Matched Model. Property, plant and equipment were expecting a negative coefficient, however, the Jones and Modified Jones Model both found positive coefficients with accruals unlike the Performance Matched and Performance Matched Free Cash Flow model. This change is a significant improvement in the Performance Matched Free Cash Flow Model and evidenced that higher returns on assets generate higher income changing accruals. The performance indicator coefficient, ROA, shows $18.21 \%$ of negative individual regressors with positive coefficients, which indicates profit increasing accruals.

\subsection{Multivariate Analysis}

This section presents the results of multivariate regression for all the significant methods of the study, including expected coefficient directions of variables. Jones' Model is the pioneer of accruals calculation, followed by the Modified Jones Model, where our analysis found that, among all variables, the Modified Jones Model has more significant effects on NZX listing tenure, business operating tenure and return on assets (ROA), with the $R^{2}$ value marginally higher in the Modified Jones Model (20.6\%) compared to the Jones Model (19.8\%) for these variables. The Fisher test shows both models are significant at a $1 \%$ level with acceptable levels of Durbin-Watson value reflecting no auto correlation in the model. As a rule of thumb, a Durbin-Watson test value lower than 2 is an acceptable level of auto correlation in the model. 
Table 7

Multivariate Analysis of the Determinant of Discretionary Accruals

\begin{tabular}{|c|c|c|c|c|}
\hline Variables & Jones Model & $\begin{array}{c}\text { Modified } \\
\text { Jones Model }\end{array}$ & $\begin{array}{c}\text { Performance } \\
\text { Matched } \\
\text { Model }\end{array}$ & $\begin{array}{c}\text { Performance } \\
\text { Matched Free Cash } \\
\text { Flow Model }\end{array}$ \\
\hline Constant & $\begin{array}{c}0.006 \\
(0.274)\end{array}$ & $\begin{array}{c}0.015 \\
(0.708)\end{array}$ & $\begin{array}{c}0.022 \\
(0.197)\end{array}$ & $\begin{array}{c}0.147 \\
(0.0828)\end{array}$ \\
\hline Regulation Dummy & $\begin{array}{c}0.004 \\
(0.155)\end{array}$ & $\begin{array}{l}-0.005 \\
(.182)\end{array}$ & $\begin{array}{c}0.021 \\
(0.861)\end{array}$ & $\begin{array}{c}0.523 \\
(2.501)^{* *}\end{array}$ \\
\hline $\begin{array}{l}\text { Corporate Governance } \\
\text { Index }\end{array}$ & $\begin{array}{c}-0.043 \\
(-1.230)\end{array}$ & $\begin{array}{c}-0.054 \\
(-1.527)\end{array}$ & $\begin{array}{c}-0.038 \\
(-1.178)\end{array}$ & $\begin{array}{c}-0.757 \\
(-2.42)^{* * *}\end{array}$ \\
\hline $\begin{array}{l}\text { Corporate Governance } \\
\text { Index * Regulation } \\
\text { Dummy }\end{array}$ & $\begin{array}{c}0.020 \\
(0.434)\end{array}$ & $\begin{array}{c}0.031 \\
(0.688)\end{array}$ & $\begin{array}{c}-0.033 \\
(-0.769)\end{array}$ & $\begin{array}{c}-0.701 \\
(-1.800)^{*}\end{array}$ \\
\hline Control Shareholder & $\begin{array}{c}-0.003 \\
(-0.430)\end{array}$ & $\begin{array}{c}-0.005 \\
(-0.760)\end{array}$ & $\begin{array}{c}-0.005 \\
(-0.879)\end{array}$ & $\begin{array}{c}0.360 \\
(5.925)^{* * *}\end{array}$ \\
\hline Listing Tenure & $\begin{array}{c}0.001 \\
(2.885)^{* * *}\end{array}$ & $\begin{array}{c}0.001 \\
(2.456)^{* *}\end{array}$ & $\begin{array}{c}0.001 \\
(3.712)^{* * *}\end{array}$ & $\begin{array}{c}-0.005 \\
(-2.300)^{* *}\end{array}$ \\
\hline Operating Tenure & $\begin{array}{c}-0.001 \\
(-3.012)^{* * *}\end{array}$ & $\begin{array}{c}-0.001 \\
(-2.905)^{* * *}\end{array}$ & $\begin{array}{c}-0.001 \\
(-5.70)^{* * *}\end{array}$ & $\begin{array}{c}0.005 \\
(4.496)^{* * *}\end{array}$ \\
\hline Leverage & $\begin{array}{c}0.006 \\
(0.459)\end{array}$ & $\begin{array}{c}-0.001 \\
(-0.038)\end{array}$ & $\begin{array}{c}0.017 \\
(1.338)\end{array}$ & $\begin{array}{c}0.028 \\
(0.257)\end{array}$ \\
\hline Return on Assets & $\begin{array}{c}0.208 \\
(9.036)\end{array}$ & $\begin{array}{c}0.233 \\
(9.609)^{* * *}\end{array}$ & $\begin{array}{c}0.021 \\
(1.178)\end{array}$ & $\begin{array}{c}-0.588 \\
(-3.878) * * *\end{array}$ \\
\hline Total Assets (t-1) & $\begin{array}{c}0.000 \\
(1.103)\end{array}$ & $\begin{array}{c}0.000 \\
(1.086)\end{array}$ & $\begin{array}{c}0.000 \\
(-0.250)\end{array}$ & $\begin{array}{c}0.000 \\
(0.120)\end{array}$ \\
\hline Primary Sector Dummy & $\begin{array}{c}-0.004 \\
(-0.344)\end{array}$ & $\begin{array}{c}-0.002 \\
(-0.179)\end{array}$ & $\begin{array}{c}-0.018 \\
(-1.954)^{*}\end{array}$ & $\begin{array}{c}0.454 \\
(5.668)^{* * *}\end{array}$ \\
\hline Energy Sector Dummy & $\begin{array}{c}-0.004 \\
(-0.519)\end{array}$ & $\begin{array}{c}-0.005 \\
(-0.643)\end{array}$ & $\begin{array}{c}-0.006 \\
(-0.745)\end{array}$ & $\begin{array}{c}0.270 \\
(3.158)^{* * *}\end{array}$ \\
\hline Goods Sector Dummy & $\begin{array}{c}0.003 \\
(0.246)\end{array}$ & $\begin{array}{c}-0.001 \\
(-0.092)\end{array}$ & $\begin{array}{c}-0.027 \\
(-2.199)^{* *}\end{array}$ & $\begin{array}{c}0.315 \\
(3.020)^{* * *}\end{array}$ \\
\hline Property Sector Dummy & $\begin{array}{c}-0.003 \\
(-0.308)\end{array}$ & $\begin{array}{c}-0.004 \\
(-0.398)\end{array}$ & $\begin{array}{c}-0.018 \\
(-2.113)^{* *}\end{array}$ & $\begin{array}{c}-0.025 \\
(-0.289)\end{array}$ \\
\hline $\begin{array}{l}\text { Investment Sector } \\
\text { Dummy }\end{array}$ & $\begin{array}{c}-0.030 \\
(-2.299)\end{array}$ & $\begin{array}{c}-0.028 \\
(-0.917)^{*}\end{array}$ & $\begin{array}{c}-0.010 \\
(-1.027)\end{array}$ & $\begin{array}{c}0.290 \\
(2.884)^{* *}\end{array}$ \\
\hline R-squared & 0.198 & 0.206 & 0.116 & 0.171 \\
\hline Adjusted R-squared & 0.177 & 0.186 & 0.093 & 0.149 \\
\hline S.E. of regression & 0.197 & 0.199 & 0.159 & 1.429 \\
\hline F-statistic & 9.597 & 10.119 & 5.115 & 8.000 \\
\hline Prob(F-statistic) & 0.000 & 0.000 & 0.000 & 0.000 \\
\hline Durbin-Watson stat & 1.327 & 1.292 & 1.547 & 1.711 \\
\hline
\end{tabular}

$*, * *, * * *$ Correlation significant at the $10 \%, 5 \%$ and $1 \%$ level (2-tailed)

Sample companies were categorised by 6 sectors, therefore 5 sector dummy variables are used in analysis. Only the service sector has no dummy to avoid the dummy variable trap which is the situation of perfect collinearity (Gujarati, 2003). In other words, $\left(\varphi_{1}\right)$ represents the intercept of the service sector and $\varphi_{11}, \varphi_{12}, \varphi_{13}, \varphi_{14}$, and $\varphi_{15}$, are the differential intercept coefficients reflecting the intercept of other sectors; Goods, Primary, Property, Energy and Investment respectively.

Performance Matched Model regression found NZX listing tenure, Operating tenure, Goods, Property and Energy sectors are statistically significant. This model has comparatively lower $R^{2}$ with a predictive value of $11.6 \%$ at the $1 \%$ significance level. Moreover, a DurbinWatson test value of 1.547 indicates no auto correlation in the model. 
Finally, the Performance Matched Free Cash Flow Model shows relatively higher significance of variables. Bradbury et al. (2006), in research about NZ firms found adjusted $R^{2}=0.075$ to 0.089 at the $1 \%$ level of significance using different specifications of Modified Jones Model (1995). The coefficient of regulation dummy for the Jones Model, Modified Jones Model, Performance Matched Model and Performance Matched Free Cash Flow Model is respectively 0.004, $-0.005,0.021$ and 0.523. Of all the models, The Performance Matched Free Cash Flow Model has significance at the 5\% level with regulation. As mentioned above, regulations have a positive impact on earnings management and $H_{0} 1$ is not rejected for the Jones Model, Performance Matched Model and Performance Matched Free Cash Flow Model. However, the Modified Jones Model alone shows a negative coefficient. It indicates that the existence of regulation reduces earnings management opportunity. In other words, a more regulated company environment minimises the opportunistic management behaviour.

Firms with higher corporate governance compliance have reduced opportunistic management attitudes which ensure higher accountability and reporting quality (Aguilera, 2005; Sinha, 2006). The coefficients of the corporate governance index for the Jones Model, Modified Jones Model, Performance Matched Model and Performance Matched Free Cash Flow Model are $-0.043,-0.054,-0.038$ and -0.757 respectively. The entire set of coefficients indicates a negative association of the corporate governance index with discretionary accruals; indicating higher compliance of corporate governance reduces managerial accruals. Performance Matched Free Cash Flow Model has statistical significance at the 1\% level. The interaction coefficient of the corporate governance index and regulation dummy (Corporate Governance Index * Regulation dummy) shows an expected negative association for both the Performance Matched Model and Performance Matched Free Cash Flow Model as -0.033 and -0.701 (at $10 \%$ level of significance); however, the Jones Model and Modified Jones Model have positive coefficients of 0.020 and 0.031 with more than a $10 \%$ level of significance. Compliant corporate governance ensures independent boards, audit processes and strong internal control systems which reduce managerial discretion. $\mathrm{H}_{0} 2$ is thus rejected and indicates that higher corporate governance compliance with regulation reduces discretionary accruals. In summary, $H_{0} 1$ and $H_{0} 2$, results indicate that the existence of corporate governance regulation alone does not reduce managerial opportunistic behaviour but regulation with higher compliance of corporate governance does reduce managerial discretion.

The coefficient for Control Shareholdings in the Performance Matched Free Cash Flow Model is calculated as 0.360 , statistically significant at a $1 \%$ level. However, the coefficient for the Jones Model, Modified Jones Model and Performance Matched Free Cash Flow Model is calculated as $-0.003,-0.005$ and -0.005 respectively, at more than a $10 \%$ level of statistical significance. The positive association of discretionary accruals and control shareholdings is consistent with the rejection of $\mathrm{H}_{0} 3$, suggesting that concentrated ownership holds significant control over management incurring discretionary accruals (Bradbury, et al., 2006). Control shareholders have significant influence in selecting directors and CEOs of firms which indirectly influences managerial discretion.

The coefficients of firm operating tenure for the Jones Model, Modified Jones Model, Performance Matched Model and Performance Matched Free Cash Flow Models are -0.001, $0.001,-0.001$ and 0.005 respectively. Firm operating tenure is statistically significant at the $1 \%$ level for each of the models. Firms operating for longer terms having higher discretionary accruals were supported in rejecting $H_{0} 4$.

The coefficient of the Jones Model, Modified Jones Model, and Performance Matched Models for listing tenure is 0.001 each while the Performance Matched Free Cash Flow Models shows 0.005 . Moreover, stock exchange listing tenure is statistically significant at a 5\% level for both the Modified Jones Model and Performance Matched Free Cash Flow 
Model, and similarly, at a 1\% level of significance for the Jones Model and Performance Matched Model. As argued, stock exchange listing tenure has statistically significant negative associations in the Performance Matched Model therefore $H_{0} 5$ is rejected.

Performance indicator ROA has a negative coefficient of -0.588 for the Performance Matched Free Cash Flow Model with 1\% level significance and the Modified Jones Model has a coefficient of 0.233 at that level. However, the Jones Model and Performance Matched Model do not have any statistical significance with discretionary accruals. The negative association indicates that high performance reduces managerial discretion: managers are still demotivated when they meet targeted performance. However, leverage and firm size do not show any statistical significance at the $10 \%$ level.

Among NZX listed companies; primary, energy and goods sectors show statistical significance at a $1 \%$ level in the Performance Matched Free Cash Flow Model. Similarly, the Investment sector shows a 5\% level of significance in the same Model. The Performance Matched Model shows significance in the Primary sector at a $10 \%$ level; goods and property sector returns at a 5\% level of significance. The Modified Jones Model indicates a $10 \%$ level of significance for the investment sector only. However, none of the sectors result in statistical significance for the Jones Model. Therefore, compared with four measures of discretionary accruals, the Performance Matched Free Cash Flow Model reflects more significance in a sectoral analysis of managerial discretion. Finally, the existing interaction between corporate governance and regulation suggests a negative coefficient, as expected. This implies that existing regulations enhance corporate governance compliance that subsequently reduces discretionary accruals.

\section{Conclusions and Remarks}

This paper expands the stream of earnings management model using discretionary accruals, implementing free cash flow and documenting that firms demonstrating higher compliance of corporate governance have relatively lower discretionary accruals. The free cash flow measure is one of the very few observable inputs available in discretionary accruals models. Earnings management literature evidenced that accruals models are suitable for explanation using cash flow type operating activities.

The results depict corporate governance compliance increasing the accountability of management and reducing financial discretion in decision making. Moreover, New Zealand Stock Exchange listed companies are compelled to follow corporate governance regulation and provide better monitoring of earnings with consequently lower discretionary accruals. Discretionary accruals reduce relatively in growing firms and those in the initial stage of operation. Managerial discretion reduces as corporate governance regulation compliance improves and minimises discretionary accruals. This paper finds evidence consistent with the proposition that firms complying with corporate governance regulation have more efficient monitoring compared to low compliance firms.

An additional contribution of this paper is to determine that a regulated environment of corporate governance reduces managerial opportunistic behaviour. Moreover, the evidence shows the 'comply or explain' nature of soft regulation is effective in New Zealand and that it reduces managerial discretionary accruals. The findings of this paper are beneficial for not only New Zealand corporate governance legislators but for other countries in developing or restoring corporate governance guidelines. 


\section{References}

Aguilera, R. (2005). Corproate Governance and Director Accountability: an Institutional comparative Perspective. British Journal of Management, 16, 39-53. http://dx.doi.org/10.1111/j.1467-8551.2005.00446.x

Ball, R., Kothari, S. P., \& Robin, A. (2000). The effect of international institutional factors on properties of accounting earnings. Journal of Accounting and Economics, 29(1), 1-51. http://dx.doi.org/10.1016/S0165-4101(00)00012-4

Balsam, S., Krishnan, J., \& Yang, J. (2003). Auditor Industry Specialization and Earnings Quality. Auditing: A Journal of Practice \& Theory, 22, 71-97. http://dx.doi.org/10.2308/aud.2003.22.2.71

Bartle, I., \& Vass, P. (2007). Self-Regulation within the Regulatory State: Towards a New Regulatory Paradigm? Public Administration, 85(4), 885-905. http://dx.doi.org/10.1111/j.1467-9299.2007.00684.x

Berghe, L., \& Levrau, A. (2004). Evaluating Board of Directors: What constitutes a good corporate board? Corporate Governance: An International Review, 12(4), 461-478. http://dx.doi.org/10.1111/j.1467-8683.2004.00387.x

Bradbury, M. E., Mak, Y. T., \& Tan, S. M. (2006). Board Characteristics, Audit Committee Characteristics and Abnormal Accruals. Pacific Accounting Review, 18(2), 47-68. http://dx.doi.org/10.1108/01140580610732813

Bukit, B. R., \& Iskandar, M. T. (2009). Surplus Free Cash Flow, Earnings Management and Audit Committee. International Journal of Economics and Management, 3(1), 204223.

Burgstahler, D., \& Dichev, I. (1997). Earnings management to avoid earnings decreases and losses. Journal of Accounting and Economics, 24(1), 99-126. http://dx.doi.org/10.1016/S0165-4101(97)00017-7

Cadbury, A. (1992). Report of the committee on the financial aspects of corporate governance. London.

Cahan, S., Emanuel, D., Hay, D., \& Wong, N. (2008). Non-audit fees, long-term auditorclient relationships and earnings management. Accounting and Finance, 48, 181-207. http://dx.doi.org/10.1111/j.1467-629X.2008.00251.x

DeAngleo, L. (1986). Accounting numbers as market valuation substitutes: a study of management buyiuts of public shareholders. The Accounting Review, 61(3), 400-420.

Dechow, P., Sloan, R., \& Sweeney, A. (1995). Detecting earnings management. Accounting Review, 193-225.

Dechow, P. M., \& Dichev, I. (2002). The Quality of Accruals and Earnings: The Role of Accruals Estimation Errors. The Accounting Review, 77(Suppliment), 35-59. http://dx.doi.org/10.2308/accr.2002.77.s-1.35

Dechow, P. M., \& Ge, W. (2006). The persistence of earnings and cash flows and the role of special items: Implications for the accrual anomaly. Review of Accounting Studies, 11, 253-296. http://dx.doi.org/10.1007/s11142-006-9004-1

Dechow, P. M., Sloan, R. G., \& Sweeney, A. P. (1995). Detecting Earnings Management. The Accounting Review, 70(2), 193-225.

Degeorge, F., Patel, J., \& Zeckhauser, R. (1999). Earnings Management to Exceed Thresholds. The Journal of Business, 72(1), 1-33. http://dx.doi.org/10.1086/209601

Drobietz, W. (2002). Corporate Governance - Legal Fiction or Economic Reality. Financial Markets and Portfolio Management, 16(4), 431-439. http://dx.doi.org/10.1007/s11408-002-0401-6

Fasterling, B. (2005). Best practices and better laws: Corporate governance codes in the member states of the European Union ERA-Forum, 6(3). 
Francis, J., Nanda, D., \& Olsson, P. (2008). Voluntary disclosure, earnings quality and cost of capital. Journal of Accounting Research, 46(1), 53-99.

http://dx.doi.org/10.1111/j.1475-679X.2008.00267.x

Gujarati, D. N. (2003). Basic Econometrics (Fourth ed.). New York: McGraw Hill.

Habib, A., \& Islam, A. (2007). Determinants and Consequences of non-audit service fees Preliminary evidence from Bangladesh. Managerial Auditing Journal, 22(5), 446-469. http://dx.doi.org/10.1108/02686900710750748

Hart, O. (1995). Corporate Governance; Some Theory and Implications. The Economic Journal, 105(430), 679-689. http://dx.doi.org/10.2307/2235027

Healy, P. M. (1985). The effect of bonus schemes on accounting decision. Journal of Accounting and Economics, 7(1-3), 85-107. http://dx.doi.org/10.1016/01654101(85)90029-1

Hermes, N., Postma, T., \& Zivkov, O. (2007). Corporate Governance Codes and their contents: An analysis of Eastern European codes. Journal of East European Management Studies, 12(1), 53-74.

Ingram, R. W., \& Lee, T. A. (2007). information Provided by Accrual and Cash-Flow Measures of Operating Activities. ABACUS, 33(2), 168-185. http://dx.doi.org/10.1111/1467-6281.00010

Jiang, W., Lee, P., \& Anandarajan, A. (2008). The association between corporate governance and earnings quality: Further evidence using the GOV-Score Advances in Accounting, 24(2). http://dx.doi.org/10.1016/j.adiac.2008.08.011

Jones, J. J. (1991). Earnings Management During Import Relief Investigations. Journal of Accounting Research, 29(2), 193-228. http://dx.doi.org/10.2307/2491047

Klein, A. (2002). Audit committee, board of director characteristics, and earnings management. Journal of Accounting and Economics, 33(3), 375-400. http://dx.doi.org/10.1016/S0165-4101(02)00059-9

Klein, A. (2003). Firm performance and board committee structure. Journal of Law and Economics, 41, 275-303. http://dx.doi.org/10.1086/467391

Kole, S., \& Lehn, K. (1997). Deregulation, the Evolution of Corporate Governance Structure and Survival. The American Economic Review, 87(2), 421-425.

Kothari, S. P., Leone, A., \& Wasley, C. E. (2005). Performance matched discretionary accrual measures. Journal of Accounting and Economics, 39(1), 163-197. http://dx.doi.org/10.1016/j.jacceco.2004.11.002

Lara, J., Osmab, B., \& Penalvac, F. (2007). Board of Directors' Characteristics and Conditional Accounting Conservatism: Spanish Evidence European Accounting Review, 16(4), 727-755.

Larcker, D., \& Richardson, S. (2004). Fees Paid to Audit Firms, Accrual Choices, and Corporate Governance. Journal of Accounting Literature, 42(3), 625-658. http://dx.doi.org/10.1111/j.1475-679X.2004.t01-1-00143.x

Larcker, D., Richardson, S., \& Irem, T. (2005). How Important is Corporate Governance. Working Paper.

Larcker, D., Richardson, S., \& Tuna, I. (2007). Corporate Governance, Accounting Outcomes and Organizational Performance. The Accounting Review, 82(4), 963-1008. http://dx.doi.org/10.2308/accr.2007.82.4.963

Leuz, C., Nanda, D., \& Wysocki, P. D. (2003). Earnings management and investor protection: an international comparison. Journal of Financial Economics, 69(3), 505-527. http://dx.doi.org/10.1016/S0304-405X(03)00121-1

Luan, C.-J., \& Tang, M.-J. (2007). Where is Independent Director Efficacy. Corporate Governance: An International Review, 15(4). 
McNichols, M. (2000). Research design issues in earnings management studies. Journal of Accounting and Public Policy, 19, 313-345. http://dx.doi.org/10.1016/S02784254(00)00018-1

McNichols, M., \& Wilson, G. P. (1988). Evidence of Earnings Management from the Provision for Bad Debts Journal of Accounting Research, 26, 1-31.

Moyer, S. E. (1990). Capital adequacy ratio regulations and accounting choices in commercial banks. Journal of Accounting and Economics, 13(2), 123-154. http://dx.doi.org/10.1016/0165-4101(90)90027-2

New Zealand Corporate Governance Best Practice Code (2004).

Peasnell, K. V., Pope, P. F., \& Young, S. (2005). Board Monitoring and Earnings Management: Do Outside Directors Influence Abnormal Accruals? Journal of Business finance and accounting, 32(7 \& 8), 1311-1346. http://dx.doi.org/10.1111/j.0306-686X.2005.00630.x

Petroni, K. R. (1992). Optimistic reporting in the property- casualty insurance industry. Journal of Accounting and Economics, 15(4), 485-508. http://dx.doi.org/10.1016/0165-4101(92)90003-K

Richardson, S. A., Sloan, R. G., Soliman, M. T., \& Tuna, I. (2005). Accrual reliability, earnings persistence and stock prices. Journal of Accounting and Economics, 39(3), 437-485. http://dx.doi.org/10.1016/j.jacceco.2005.04.005

Romano, R. (2005). Is regulatory competition a problem or irrelevant for corporate governance? Oxford Review of Economic Policy, 21(2), 212-231. http://dx.doi.org/10.1093/oxrep/gri013

Ronen, J., \& Yaari, V. (2007). Earnings Management: Emerging Insights in Theory, Practice and Research. New York: Springer.

Shen, C.-H., \& Chih, H.-L. (2007). Earnings Management and Corporate Governance in Asia's Emerging Markets. Corporate Governance: An International Review, 15(5), 999-1021. http://dx.doi.org/10.1111/j.1467-8683.2007.00624.x

Sinha, R. (2006). Regulation The market for corproate control and corporate governance. Global Finance Journal, 16, 264-282. http://dx.doi.org/10.1016/j.gfj.2006.01.001

Siregar, S. V., \& Utama, S. (2008). Types of earnings management and the effect of ownership strcuture, firm size and corporate-governance practice: Evidence from Indonesia. The International Journal of Accounting, 43, 1-27. http://dx.doi.org/10.1016/j.intacc.2008.01.001

Smith, A. (1776). The Wealth of Nations. New York: Cannon Edition.

Strenger, C. (2004). The Corporate Governance Scorecard: a tool for the implementation of corporate governance. Corporate Governance: An International Review, 12(1), 11-15. http://dx.doi.org/10.1111/j.1467-8683.2004.00339.x

Teoh, S. H., \& Wong, T. J. (1993). Perceived Auditor Quality and the Earnings Response Coefficient. The Accounting Review, 68(2), 346-366.

Tosi, H., Shen, W., \& Gentry, R. (2003). Why Outsiders on Boards Can't Solve the Corporate Governance Problem. Organizational Dynamics, 32(2), 180-192. http://dx.doi.org/10.1016/S0090-2616(03)00017-2

Vafeas, N. (2000). Board structure and informativeness of earnings. Journal of Accounting and Public Policy, 19, 139-160. http://dx.doi.org/10.1016/S0278-4254(00)00006-5

Vance, S. C. (1983). Corporate Leadership: Board, Directors and Strategy. New York: McGraw-Hill.

Varma, V. S., Patel, A., \& Naidu, D. (2009). Shareholder Concentration and Discretionary Accruals: Evidence from an Emerging Market. The IUP Journal of Accounting Research and Audit Practices, VIII(2), 7-16. 
Warfield, T. D., Wild, J. J., \& Wild, K. L. (1998). Managerial Ownership, Accounting choice and Informativeness of Earnings. Journal of Accounting and Economics, 20, 61-92. http://dx.doi.org/10.1016/0165-4101(94)00393-J

Weisbach, M. S. (1988). Outsider director and CEO turnover. Journal of Financal Economics, 20, 431-460. http://dx.doi.org/10.1016/0304-405X(88)90053-0

Xie, B., Davidson, W. N., \& DaDalt, P. J. (2003). Earnings management and corporate governance: the role of the board and the audit committee. Journal of Corporate Finance, 9(3), 295-316. http://dx.doi.org/10.1016/S0929-1199(02)00006-8 